\title{
Flood of June 17, 1990, in the Clear Creek Basin, East-Central lowa
}

\section{By KIMBERLEE K. BARNES AND DAVID A. EASH}

\section{U.S. GEOLOGICAL SURVEY}

Open-File Report 94-78

\section{Prepared in cooperation with the}

lowa Highway Research Board and the

Highway Division of the lowa Department

of Transportation

(Research Project HR-140) 


\title{
U.S. DEPARTMENT OF THE INTERIOR \\ BRUCE BABBITT, Secretary
}

\author{
U.S. GEOLOGICAL SURVEY
}

GORDON P. EATON, Director

For additional information write to:

District Chief

U.S. Geological Survey

Rm. 269, Federal Building

400 South Clinton Street

lowa City, lowa 52244
Copies of this report can be purchased from:

U.S. Geological Survey Earth Science Information Center Open-File Reports Section Box 25286, MS 517

Denver Federal Center Denver, Colorado 80225 


\section{CONTENTS}

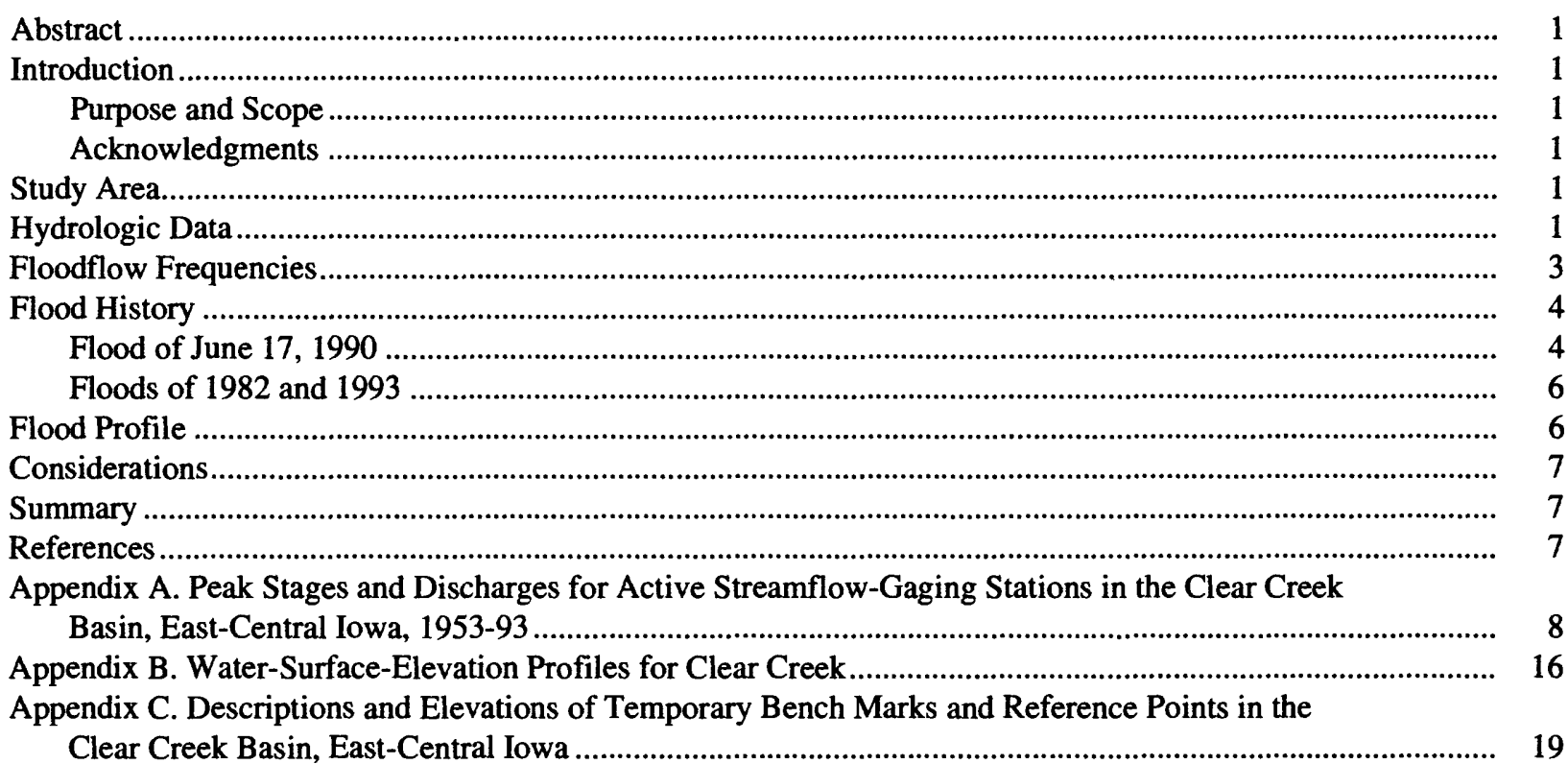

\section{FIGURES}

1. Map showing location of active U.S. Geological Survey streamflow-gaging stations in the Clear Creek Basin 2

2. Graphs showing water-surface-elevation profiles for Clear Creek ................................................... 16

\section{TABLES}

1. Floodflow frequencies for active streamflow-gaging stations in the Clear Creek Basin

2. Selected flood-peak discharges, recurrence intervals, and unit runoff for active streamflow-gaging stations in the Clear Creek Basin 
CONVERSION FACTORS, ABBREVIATIONS, AND VERTICAL DATUM

\begin{tabular}{rll}
\hline Multiply & By & To obtain \\
\hline & & \\
inch (in.) & 25.4 & millimeter \\
foot $(\mathrm{ft})$ & 0.3048 & meter \\
mile $(\mathrm{mi})$ & 1.609 & kilometer \\
square $\left.\mathrm{mile}^{2} \mathrm{mi}^{2}\right)$ & 2.590 & square kilometer \\
cubic foot per second $\left(\mathrm{ft}^{3} / \mathrm{s}\right)$ & 0.02832 & cubic meter per second \\
cubic foot per second per square & 0.01093 & cubic meter per second per square kilometer \\
mile $\left[\left(\mathrm{ft}^{3} / \mathrm{s}\right) / \mathrm{mi}^{2}\right]$ & &
\end{tabular}

Sea level: In this report, "sea level" refers to the National Geodetic Vertical Datum of 1929--a geodetic datum derived from a general adjustment of the first-order level nets of the United States and Canada, formerly called Sea Level Datum of 1929. 


\title{
Flood of June 17, 1990, in the Clear Creek Basin, East-Central lowa
}

\author{
By Kimberlee K. Barnes and David A. Eash
}

\section{Abstract}

A water-surface-elevation profile for the flood of June 17, 1990, in the Clear Creek Basin, east-central Iowa, is given in this report. The maximum flood-peak discharge of 10,200 cubic feet per second for the streamflowgaging station on Clear Creek near Coralville, Iowa (station number 05454300 ), occurred on June 17, 1990. This discharge was approximately equal to the 80 -year recurrence-interval discharge. A flood history describes rainfall conditions for floods that occurred during 1982, 1990, and 1993.

\section{INTRODUCTION}

Evaluation of flood hazards and the planning, design, and operation of various structures on flood plains require information about floods. Flood reports supply specific information for selected floods and are used by planners and engineers to evaluate the magnitude and frequency of floods in a river basin.

\section{Purpose and Scope}

This report presents a water-surface-elevation profile for the flood of June 17, 1990, in the Clear Creek Basin in east-central Iowa. It provides information on flood stages and discharges, floodflow frequencies, and bench-mark and referencepoint descriptions and elevations for the Clear Creek Basin. Rainfall conditions for floods that occurred during 1982, 1990, and 1993 are provided for comparison purposes.

\section{Acknowledgments}

This report was prepared by the U.S. Geological Survey (USGS) in cooperation with the
Iowa Highway Research Board and the Highway Division of the Iowa Department of Transportation. Various Federal, State, and local agencies cooperated in the collection of streamflow records used in this report, the acknowledgment of which is contained in the annual water-data reports of the USGS (U.S. Geological Survey, 1953-93).

\section{STUDY AREA}

The Clear Creek Basin is located in eastcentral Iowa, includes parts of Iowa and Johnson Counties, and drains as a right-bank tributary to the Iowa River within the city of Coralville (fig. 1). The basin is oriented in a general west-east direction and drains $105 \mathrm{mi}^{2}$.

The topography of the Clear Creek Basin is characterized by uplands, dissected by tributary streams. The dissected uplands form rolling hills with flat areas on the divides (Schwob, 1964, p. 8-9). The basin has a relatively broad and flat flood plain adjoining Clear Creek, which has a meandering low-water channel except for reaches that have been straightened. Land use in the basin is primarily agricultural with some livestock operations.

Mean annual precipitation for 1961-90 in the Clear Creek Basin was 36.31 in., as determined from rain gages located in Iowa City and Williamsburg (Harry Hillaker, Iowa Department of Agriculture and Land Stewardship, State Climatology Office, oral commun., July 1993). Mean annual runoff for 1953-92 in the basin was 9.18 in. as determined at the Clear Creek near Coralville streamflow-gaging station (station number 05454300) (U.S. Geological Survey, 1993, p. 101).

\section{HYDROLOGIC DATA}

Gaging-station records are the primary source of data for analyzing and understanding the flood 


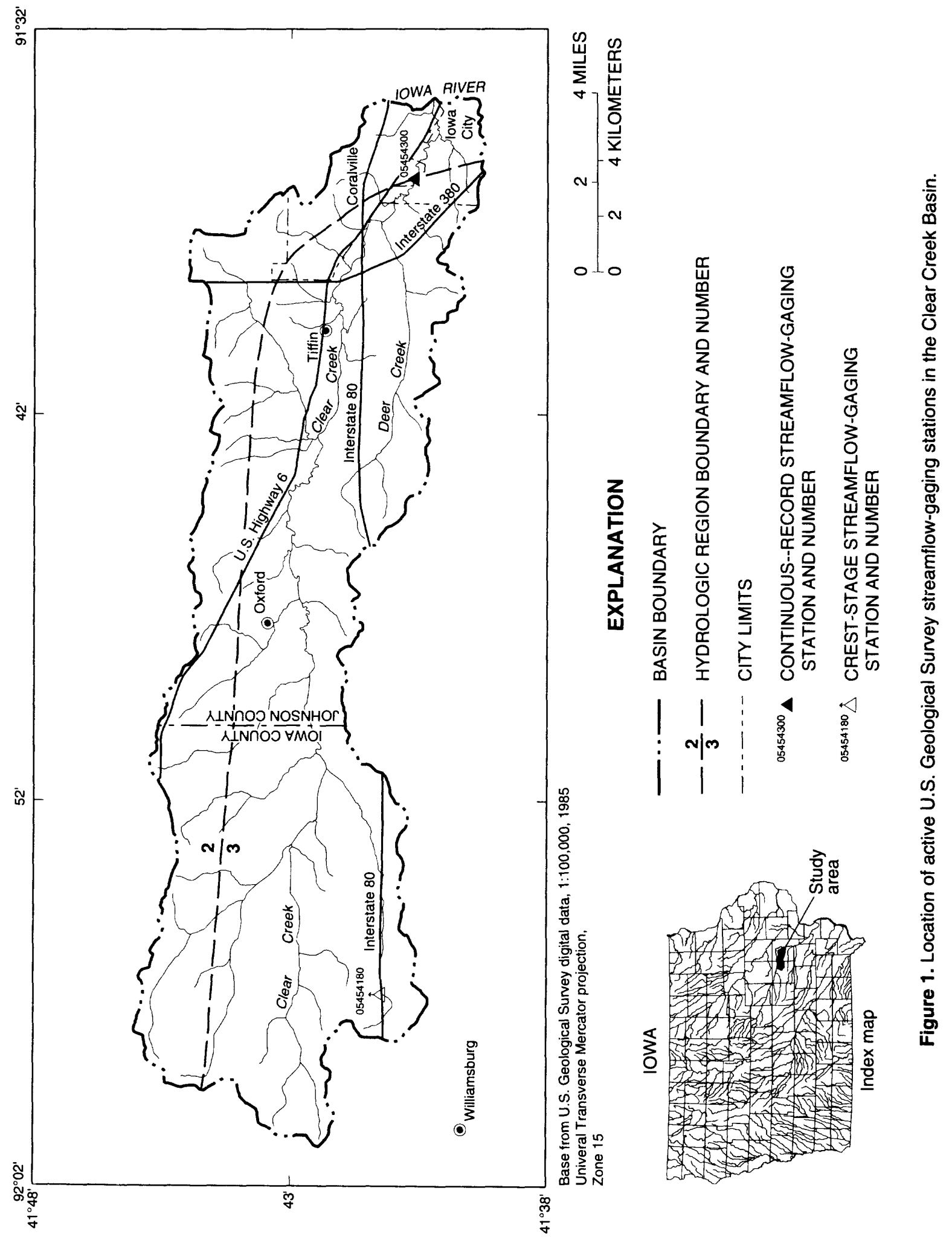


hydrology of a river basin. Flood information is obtained from complete-record streamflow-gaging stations, which provide a continuous chronology of streamflow, and from partial-record, crest-stage streamflow-gaging stations, which provide a chronology of annual peak flows. The location of the two active USGS gaging stations in the Clear Creek Basin, one continuous-record and one crest-stage gaging station, are shown in figure 1 . The specific location, annual peak stages and discharges, and other information pertaining to each gaging station are presented in Appendix A. Discharge records for these gaging stations are published in the annual water-data reports of the USGS (U.S. Geological Survey, 1953-93).

The computation of discharge records at a gaging station is dependent upon the development of a stage-discharge relation, or rating curve, between water-surface elevations (stages) and the corresponding flow rates (discharges). The highwater part of the stage-discharge relation generally remains stable if the channel downstream from the gaging station remains unchanged. Changes in the stage-discharge relation occur from time to time, either gradually or abruptly, due to changes in the river channel that result from scour, deposition, or the growth of vegetation (Rantz and others, 1982, p. 328-360).

\section{FLOODFLOW FREQUENCIES}

The magnitude and frequency of flood discharges, or floodflow frequencies, for a streamflow-gaging station are determined from a flood-frequency curve that relates observed annual-peak discharges to annual exceedance probability or recurrence interval. Annual exceedance probability is expressed as the chance that a given flood magnitude will be exceeded in any 1 year. Recurrence interval, which is the reciprocal of the annual exceedance probability, is the statistical average number of years between exceedances of a given flood. For example, a flood with a magnitude that is expected to be exceeded once on the average during any 100-year period (recurrence interval) has a 1-percent chance (annual exceedance probability $=0.01$ ) of being exceeded during any 1 year. This flood, commonly termed the 100-year flood, is the theoretical peak discharge against which actual flood peaks generally are compared. Although the recurrence interval represents the long-term average period between floods of a specific magnitude, rare floods could occur at shorter intervals or even within the same year.

The method for determining floodflow frequencies is outlined in Bulletin 17B of the Interagency Advisory Committee on Water Data (IACWD, 1982, p. 1-28). The IACWD recommends using the Pearson Type-III distribution with $\log$ transformation of the data as a base method for determining floodflow frequencies. At least 10 years of gaged annual-peak discharges are required to compute floodflow frequencies. In this report, this method for determining floodflow frequencies is referred to as the "Bulletin 17B" method.

Floodflow frequencies computed for a gaging station and recurrence intervals determined for selected flood peaks are statistics that can change when recalculated as more data become available. Statistics become more reliable as more data are collected and used in the computations. USGS streamflow-gaging stations are the primary source of the streamflow data used in the computations.

Other methods for determining floodflow frequencies at stream sites in Iowa, including those not gaged, are described by Lara (1987, p. 2-19) and Eash (1993, p. 9-41). Lara (1987) used the physiographic characteristics of Iowa as a guide in defining the boundaries of five hydrologic regions. Regional equations were developed by using the floodflow frequencies for all gaged stations in a hydrologically, homogeneous area, thereby reducing potential errors associated with nonrepresentative, short-term stations. For this reason, a regional analysis may produce improved estimates of the flood characteristics at gaged sites.

Two new methods for estimating floodflow frequencies for stream sites in Iowa were developed by Eash (1993). Statewide, drainagebasin equations were developed by relating significant drainage-basin characteristics (quantified using a geographic-information-system procedure) to the floodflow frequencies for 164 streamflowgaging stations in Iowa. Secondly, statewide and regional channel-geometry equations were developed by relating significant channel-geometry characteristics (measured onsite) to the floodflow frequencies for 157 streamflow-gaging stations in 
Iowa. Lara (1987) and Eash (1993) both used the Bulletin 17B method as the base method for developing their flood-estimation equations.

The floodflow frequencies computed using the Bulletin 17B method, the regional method of Lara (1987), and the drainage-basin and channelgeometry characteristic methods of Eash (1993) for the active gaging stations in the Clear Creek Basin are listed in table 1 . The discharges determined by the Bulletin 17B method use data collected through the 1993 water year.

The Clear Creek Basin has parts of its drainage area in two of the hydrologic regions defined by Lara (1987); approximately 22 percent of the drainage area is in region 2 , and 78 percent is in region 3 (fig. 1). Therefore, regional floodflowfrequency estimates for intrabasin sites in the Clear Creek Basin may use more than one regional, flood-frequency equation. Because the Clear Creek near Coralville gaging station has a drainage basin situated in more than one hydrologic region, weighted averages based on drainage-area ratios were used to compute the regional floodflow frequencies listed in table 1 according to Lara (1987).

\section{FLOOD HISTORY}

Continuous records of streamflow have been collected since October 1952 at the USGS streamflow-gaging station on Clear Creek near Coralville (station number 05454300). Selected flood-peak discharges, including maximum known flood-peak discharges, and recurrence intervals for active streamflow-gaging stations in the Clear Creek Basin are listed in table 2.

\section{Flood of June 17, 1990}

In east-central Iowa, June 1990 was the wettest month on record, with an average of $11.59 \mathrm{in}$. of rain (previous record, 10.47 in., June 1924) (Harry Hillaker, Iowa Department of Agriculture and Land Stewardship, State Climatology Office, oral commun., October 1993; National Oceanic and Atmospheric Administration, 1990). For June $16-17,1990,4.90$ and 5.66 in. of rainfall were recorded in Iowa City and Williamsburg, respectively. June 1990 floods affected much of central and east-central Iowa, resulting in State disaster declarations for 44 of Iowa's 99 counties,

Table 1. Floodflow frequencies for active streamflow-gaging stations in the Clear Creek Basin

[17B, Bulletin 17B (Interagency Advisory Committee on Water Data, 1982); Lara, floodflow-frequency equations for hydrologic regions 2 and 3 (Lara, 1987, p. 28). For the Clear Creek near Coralville gaging station with a basin situated in more than one hydrologic region, weighted averages based on drainage-area ratios were used; DB, drainage-basin characteristic floodflow-frequency equation (Eash, 1993, p. 17); CG, channel-geometry characteristic floodflow-frequency equation (Region I, bankfull; Eash, 1993, p. 25); --, not determined]

\begin{tabular}{|c|c|c|c|c|c|c|c|c|}
\hline \multirow{2}{*}{$\begin{array}{c}\text { Station } \\
\text { number } \\
\text { (fig. 1) }\end{array}$} & \multirow[b]{2}{*}{ Station name } & \multirow[b]{2}{*}{ Method } & \multicolumn{6}{|c|}{$\begin{array}{l}\text { Discharge, in cubic feet per second, for indicated } \\
\text { recurrence interval, in years }\end{array}$} \\
\hline & & & 2 & 5 & 10 & 25 & 50 & 100 \\
\hline \multirow[t]{4}{*}{05454180} & Clear Creek & $17 \mathrm{~B}$ & -- & -- & -- & -- & -- & - \\
\hline & tributary near & Lara & 69.6 & 147 & 216 & 321 & 406 & 502 \\
\hline & Williamsburg & DB & -- & -- & -- & -- & -- & -- \\
\hline & & $\mathrm{CG}$ & - & -- & -- & -- & - & - \\
\hline \multirow[t]{4}{*}{05454300} & Clear Creek near & $17 \mathrm{~B}$ & 1,880 & 3,610 & 5,030 & 7,110 & 8,840 & 10,700 \\
\hline & Coralville & Lara & 2,320 & 4,190 & 5,620 & 7,540 & 9,000 & 10,600 \\
\hline & & DB & 2,300 & 4,170 & 5,620 & 7,510 & 9,020 & 10,600 \\
\hline & & CG & 2,150 & 4,250 & 5,910 & 8,380 & 10,200 & 12,500 \\
\hline
\end{tabular}




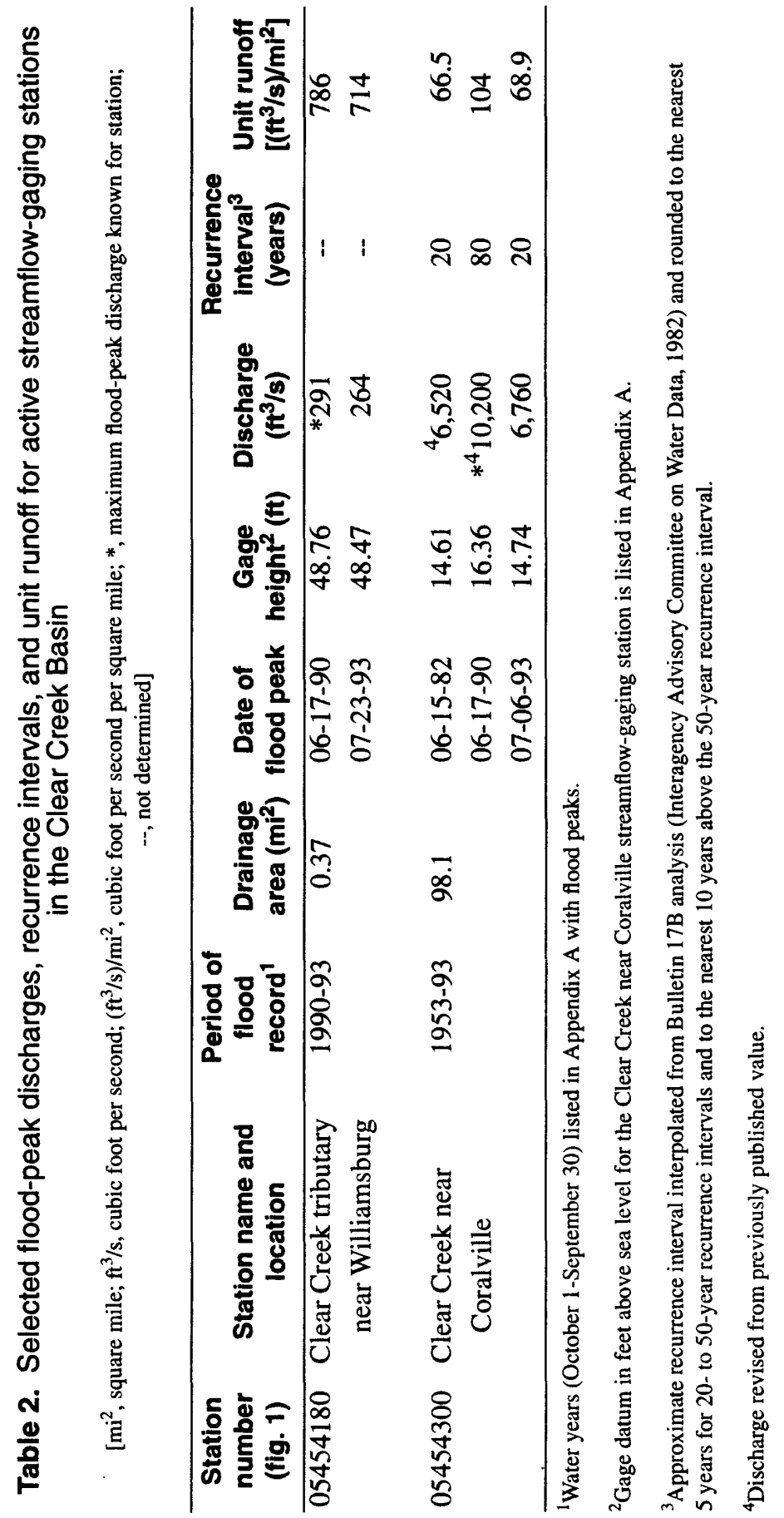


with 33 of these counties, receiving Federal disaster designations.

In Tiffin, about one-third of the homes had flooded basements, and residents of a south-side neighborhood had to be evacuated when their trailer homes were threatened by the rising water of Clear Creek (Des Moines Register, June 18, 1990). A 2-mi stretch of Interstate 80 near Coralville was closed for about 14 hours because of inundation by Clear Creek floodwaters. Traffic was detoured for 5 mi until Interstate 80 was reopened on the afternoon of June 17.

At the Clear Creek near Coralville streamflowgaging station, the peak discharge recorded on June 17,1990 , is the maximum discharge for the period of record (table 2). This flood peak of $10,200 \mathrm{ft}^{3} / \mathrm{s}$ had a recurrence interval of approximately 80 years.

\section{Floods of 1982 and 1993}

Antecedent wet conditions and intense rains on June 15, 1982, contributed to general flooding over a large area in east-central Iowa (Heinitz, 1986). Floodwaters from Clear Creek inundated Interstate 80 near Coralville. June 15th rainfalls of 4.02 and $6.15 \mathrm{in}$. were recorded in Iowa City and Williamsburg, respectively (National Oceanic and Atmospheric Administration, 1982). At the Clear Creek near Coralville gaging station, the flood peak of $6,520 \mathrm{ft}^{3} / \mathrm{s}$ on June 15,1982 , had a recurrence interval of approximately 20 years and is the third largest peak discharge on record.

From mid-June through early August 1993, severe flooding in a nine-state area in the upper Mississippi River Basin followed intense and persistent rain from January through July. Flood-peak discharges that exceeded the 10-year recurrence interval were recorded at 154 streamflow-gaging stations in the flooded region during June through August 1993 (Parrett and others, 1993). On July 6, 1993, floodwaters from Clear Creek again inundated Interstate 80 near Coralville. For July 5-6, 1993, 3.60 and 5.68 in. of rainfall were recorded in Iowa City and Williamsburg, respectively (Harry Hillaker, Iowa Department of Agriculture and Land Stewardship, State Climatology Office, oral commun., September 1993). At the Clear Creek near
Coralville gaging station, the flood peak of $6,760 \mathrm{ft}^{3} / \mathrm{s}$ on July 6,1993 , had a recurrence interval of approximately 20 years and is the second largest peak discharge on record.

\section{FLOOD PROFILE}

The water-surface-elevation profile for the June 17, 1990, flood on Clear Creek is shown in Appendix B (fig. 2). Flood elevations located both upstream and downstream from bridges were identified within a few days of passage of the flood peak and were referenced to a common datum by leveling. A December 22, 1993, low-water profile also is shown in figure 2 to indicate the approximate range of stage that can occur within the profiled reach. The profiles were defined using data obtained by the USGS. Profiles between the bridges are straight-line interpolations, which provide only an approximation of the water-surface elevations.

For comparison, flood elevations are shown in figure 2 for June 15, 1982, and July 6, 1993, at the Clear Creek near Coralville gaging station. Flood elevations for July 6, 1993, upstream of the Interstate 80 bridge and upstream of the First Avenue and U.S. Highway 6 bridges in Coralville also are shown in figure 2 . The reach downstream of the Clear Creek near Coralville gaging station is subject to backwater from the Iowa River. On July 6, 1993, high water from the Iowa River caused the flood elevations at the First Avenue and U.S. Highway 6 bridges to exceed those of the July 17 , 1990, flood.

River miles, determined from the most current 1:24,000-scale USGS topographic maps, are referenced to the mouth of Clear Creek. Bridges are designated by an index number that helps to identify their location. For example, 7906-8NE refers to a location in Township 79 North, Range 6 West, northeast $1 / 4$ section 8 .

Differential leveling was performed to reference all the points along the profiles to a common datum. A bench mark and a reference point were established at the majority of the bridges in the profiled reach. Bench-mark and reference-point descriptions and elevations are listed in Appendix C. 
Bridge-deck and low-bridge-chord elevations are shown in figure 2 to indicate the relation between the elevation of the bridges and the elevation of the profiled flood and the low-water profile. For sloping bridges, the profiled bridgedeck and low-bridge-chord elevations represent the lower ends of the bridges.

\section{CONSIDERATIONS}

The user of this report is cautioned that the stage-discharge data presented herein are representative of the physical conditions of the basin at the time of the floods described. Changes in the basin can alter the flood magnitude for a given frequency. Examples of these basin changes include, but are not limited to, extensive urbanization, implementation of agricultural conservation practices, and installation of drainage systems. Changes in the channel conditions immediately downstream from a streamflow-gaging station can substantially affect the stage-discharge relation. Examples of such changes include the construction of dams, bridges, or levees; changes in the floodplain vegetative cover; straightening of the channel; and natural scour and fill. Temporary changes can be caused by ice and debris jams that produce backwater conditions and may cause the water-surface elevations to plot higher than the normal profile.

\section{SUMMARY}

This report provides information on the flood of June 17, 1990, in the Clear Creek Basin in east-central Iowa. The maximum flood-peak discharge of $10,200 \mathrm{ft}^{3} / \mathrm{s}$ for the Clear Creek near Coralville streamflow-gaging station occurred on June 17, 1990, and this flood peak was approximately equal to the 80-year recurrence-interval discharge. Floodflow frequencies for active gaging stations in the Clear Creek Basin and a flood history describing rainfall conditions for floods that occurred during 1982, 1990, and 1993 also are included in this report.

\section{REFERENCES}

Des Moines Register, 1990, June 18 newspaper article.

Eash, D.A., 1993, Estimating design-flood discharges for streams in Iowa using drainage-basin and channel-geometry characteristics: U.S. Geological Survey Water-Resources Investigation Report 93-4062, 96 p.

Heinitz, A.J., 1986, Floods of June-July, 1982, in Iowa: U.S. Geological Survey Open-File Report 85-151, $18 \mathrm{p}$.

Interagency Advisory Committee on Water Data (IACWD), 1982, Guidelines for determining flood flow frequency: Hydrology Subcommittee Bulletin 17B, U.S. Geological Survey, Office of Water Data Coordination, 28 p. and appendices.

Lara, O.G., 1987, Method for estimating the magnitude and frequency of floods at ungaged sites on unregulated rural streams in Iowa: U.S. Geological Survey Water-Resources Investigation Report $87-4132,34 \mathrm{p}$.

National Oceanic and Atmospheric Administration, 1982, Climatologic data, Iowa: Asheville, N.C., monthly summaries, v. 93, no. 6,28 p.

1990, Climatologic data, Iowa: Asheville, N.C., monthly summaries, v. 101 , no. $6,27 \mathrm{p}$.

Novak, C.E., 1985, WRD data reports preparation guide: Reston, Virginia, U.S. Geological Survey, $199 \mathrm{p}$.

Parrett, Charles, Melcher, N.B., and James, R.W., 1993, Flood discharges in the upper Mississippi River Basin, 1993: U.S. Geological Survey Circular 1120-A, $14 \mathrm{p}$.

Rantz, S.E., and others, 1982, Measurement and computation of streamflow--Volume 2. Computation of discharge: U.S. Geological Survey Water-Supply Paper 2175, p. 285-631.

Schwob, H.H., 1964, Water resources of the English River, Old Mans Creek, and Clear Creek Basins in Iowa: Iowa City, Iowa, U.S. Geological Survey open-file report, $53 \mathrm{p}$.

U.S. Geological Survey, 1953-93, Water resources data, Iowa, water years 1952-92 (published annually): U.S. Geological Survey Water-Data Reports. 1993, Water resources data, Iowa, water year 1992: U.S. Geological Survey Water-Data Report IA-92-1, $374 \mathrm{p}$. 


\section{APPENDICES}

\section{APPENDIX A. PEAK STAGES AND DISCHARGES FOR ACTIVE STREAMFLOW-GAGING STATIONS IN THE CLEAR CREEK BASIN, EAST-CENTRAL IOWA, 1953-93}

The peak-stage and discharge data for this report were compiled through September 30, 1993, for the active streamflow-gaging stations located in the Clear Creek Basin. The floods, designated by calendar date, are in chronological order and grouped by water year (October 1-September 30). In general, independent flood peaks above a preselected base (partialduration series) are listed for the continuousrecord gaging station (Clear Creek near Coralville). The magnitude of the selected base discharge, given in the "Remarks" section of the headnote, was determined so that it would be equaled or exceeded on the average of about three times per year. Two flood peaks are considered independent if a plot of the recorded stages indicates a well-defined trough between the peaks and if the instantaneous discharge of the trough is 25 percent or more below that of the lower peak (Novak, 1985, p. 93). Only the annual flood peaks are listed for the crest-stage gaging station (Clear Creek tributary near Williamsburg).

The gaging-station records are arranged in downstream order as explained in the annual streamflow reports of the USGS (see "References"). The gaging stations are identified by a permanent number that also is used in figure 1 and in tables 1 and 2 of this report. The datum of the gage, when given, is sea level. Flood stage, as determined by the National Weather Service, is the stage at which overflow of the natural banks of the stream begins to cause damage in the reach in which the elevation is measured. 


\section{Clear Creek Tributary near Williamsburg, Iowa}

Location.--Lat $41^{\circ} 41^{\prime} 16^{\prime \prime}$, long $91^{\circ} 57^{\prime} 02^{\prime \prime}$, in SE1/4, sec. 36 , T.80 N., R.10 W., Iowa County, Hydrologic Unit 07080209 , at culvert on county road, 4 mi northeast of Williamsburg, $1 \mathrm{mi}$ south of county highway F35.

Drainage area.--0.37 $\mathrm{mi}^{2}$.

Gage.--Crest-stage gage.

Stage-discharge relation.--Defined by current-meter measurements and culvert rating.

Remarks.--Only annual peaks are shown.

Peak stages and discharges

[ft, feet above gage datum; $\mathrm{ft}^{3} / \mathrm{s}$, cubic feet per second]

\begin{tabular}{cccc}
\hline $\begin{array}{c}\text { Water } \\
\text { year }\end{array}$ & Date & $\begin{array}{c}\text { Gage height } \\
(\mathrm{ft})\end{array}$ & $\begin{array}{c}\text { Discharge } \\
\left(\mathrm{ft}^{3} / \mathrm{s}\right)\end{array}$ \\
\hline 1990 & June 17, 1990 & 48.76 & 291 \\
1991 & Mar. 2, 1991 & 44.82 & $(1)$ \\
1992 & July 25, 1992 & 46.97 & 131 \\
1993 & July 23, 1993 & 48.47 & 264 \\
\hline
\end{tabular}

${ }^{1}$ Discharge not determined. 


\section{Clear Creek near Coralville, Iowa}

Location.--Lat $41^{\circ} 40^{\prime} 36^{\prime \prime}$, long $91^{\circ} 35^{\prime} 55^{\prime \prime}$, in NE1/4 SE1/4 sec. 1, T.79 N., R.7 W., Johnson County, Hydrologic Unit 07080209 , on left bank $15 \mathrm{ft}$ upstream from bridge on county highway. Prior to September 25, 1992, gage located about $100 \mathrm{ft}$ upstream of bridge. $1.1 \mathrm{mi}$ west of post office in Coralville, $1.5 \mathrm{mi}$ downstream from Deer Creek, and 2.7 mi upstream from mouth.

Drainage area.--98.1 $\mathrm{mi}^{2}$.

Gage.--Water-stage encoder. Datum is $647.48 \mathrm{ft}$ above sea level. Prior to January 7, 1957, nonrecording gage at same site and datum.

Stage-discharge relation.--Defined by current-meter measurements.

Flood stage.--11 ft.

Remarks.--Base for partial-duration series, $1,000 \mathrm{ft}^{3} / \mathrm{s}$.

Peak stages and discharges

[ft, feet above gage datum; $\mathrm{ft}^{3} / \mathrm{s}$, cubic feet per second]

\begin{tabular}{cccc}
\hline $\begin{array}{c}\text { Water } \\
\text { year }\end{array}$ & Date & $\begin{array}{c}\text { Gage height } \\
(\mathrm{ft})\end{array}$ & $\begin{array}{c}\text { Discharge } \\
\left(\mathrm{ft}^{3} / \mathrm{s}\right)\end{array}$ \\
\hline 1953 & Feb. 20, 1953 & $1_{11.18}$ & 21,800 \\
& May 25, 1953 & 9.30 & 1,010 \\
1954 & Aug. 26, 1954 & 8.10 & 730 \\
1955 & Feb. 21, 1955 & 19.70 & 2850 \\
1956 & Aug. 30, 1956 & 9.52 & \\
& & & 900 \\
1957 & Jan. 22, 1957 & 6.28 & 300 \\
1958 & Sept. 5, 1958 & 9.69 & 1,020 \\
& & & \\
1959 & Feb. 27, 1959 & 11.34 & 21,500 \\
& Mar. 20, 1959 & 11.68 & 2,880 \\
& Mar. 26, 1959 & 10.22 & 1,040 \\
& Apr. 28, 1959 & 10.25 & 1,040
\end{tabular}


05454300 Clear Creek near Coralville, Iowa--Continued

Peak stages and discharges--Continued

\begin{tabular}{|c|c|c|c|}
\hline $\begin{array}{l}\text { Water } \\
\text { year }\end{array}$ & Date & $\begin{array}{l}\text { Gage height } \\
\text { (ft) }\end{array}$ & $\begin{array}{c}\text { Discharge } \\
\left(\mathrm{ft}^{3} / \mathrm{s}\right)\end{array}$ \\
\hline \multirow[t]{6}{*}{1960} & Jan. 13,1960 & 11.79 & 3,060 \\
\hline & Mar. 31, 1960 & 11.63 & 2,740 \\
\hline & June 2,1960 & 10.08 & 1,150 \\
\hline & June 4,1960 & 10.06 & 1,120 \\
\hline & July $\quad 9,1960$ & 10.27 & 1,240 \\
\hline & July 14,1960 & 10.90 & 1,840 \\
\hline \multirow[t]{2}{*}{1961} & Mar. $\quad 5,1961$ & 11.84 & 3,020 \\
\hline & Mar. 14, 1961 & ${ }^{1} 10.50$ & ${ }^{2} 1,180$ \\
\hline \multirow[t]{4}{*}{1962} & Nov. 16, 1961 & 10.99 & 1,410 \\
\hline & Mar. 20, 1962 & 12.03 & 2,740 \\
\hline & May 29,1962 & 13.31 & 5,390 \\
\hline & July 14,1962 & 13.10 & 4,160 \\
\hline 1963 & Mar. $\quad 4,1963$ & ${ }^{1} 10.83$ & ${ }^{2} 700$ \\
\hline 1964 & June 24,1964 & 10.47 & 1,280 \\
\hline \multirow[t]{5}{*}{1965} & Jan. 22,1965 & 10.98 & 1,190 \\
\hline & Apr. $\quad 6,1965$ & 11.12 & 1,600 \\
\hline & Apr. 24,1965 & 12.50 & 4,060 \\
\hline & July 10,1965 & 10.67 & 1,360 \\
\hline & Sept. 21, 1965 & 13.47 & 4,000 \\
\hline \multirow[t]{2}{*}{1966} & Feb. $\quad 9,1966$ & 11.90 & 2,460 \\
\hline & May 24, 1966 & 11.91 & 2,480 \\
\hline \multirow[t]{2}{*}{1967} & June 10,1967 & 7.74 & 648 \\
\hline & Sept. 15,1967 & 7.79 & (3) \\
\hline 1968 & Apr. 20,1968 & 7.83 & 686 \\
\hline \multirow[t]{5}{*}{1969} & Apr. $\quad 4,1969$ & 9.28 & 1,050 \\
\hline & June 28,1969 & 11.65 & 1,990 \\
\hline & June 30,1969 & 12.85 & 3,180 \\
\hline & July $\quad 9,1969$ & 12.84 & 3,160 \\
\hline & July 27,1969 & 12.14 & 2,350 \\
\hline
\end{tabular}


05454300 Clear Creek near Coralville, Iowa--Continued

Peak stages and discharges--Continued

\begin{tabular}{|c|c|c|c|}
\hline $\begin{array}{l}\text { Water } \\
\text { year }\end{array}$ & Date & $\begin{array}{c}\text { Gage height } \\
\text { (ft) }\end{array}$ & $\begin{array}{c}\text { Discharge } \\
\left(\mathrm{ft}^{3} / \mathrm{s}\right)\end{array}$ \\
\hline \multirow[t]{3}{*}{1970} & Mar. 3,1970 & 13.49 & 4,900 \\
\hline & May 14,1970 & 9.81 & 1,230 \\
\hline & Sept. 17,1970 & 10.31 & 1,410 \\
\hline 1971 & Feb. 20,1971 & ${ }^{1} 13.00$ & ${ }^{2} 1,650$ \\
\hline \multirow[t]{6}{*}{1972} & Dec. 15,1971 & 9.39 & 1,170 \\
\hline & Feb. 29,1972 & (4) & ${ }^{2} 1,200$ \\
\hline & Apr. 16,1972 & 9.00 & 1,070 \\
\hline & Apr. 21,1972 & 8.85 & 1,020 \\
\hline & July 17,1972 & 10.87 & 1,670 \\
\hline & Aug. $\quad 6,1972$ & 12.29 & 2,470 \\
\hline \multirow[t]{7}{*}{1973} & Dec. 30,1972 & ${ }^{1} 12.24$ & ${ }^{2} 1,600$ \\
\hline & Apr. 16,1973 & 9.87 & 1,260 \\
\hline & Apr. 21,1973 & 12.23 & 2,430 \\
\hline & May 2,1973 & 10.69 & 1,570 \\
\hline & May 7,1973 & 9.27 & 1,090 \\
\hline & May 27,1973 & 11.53 & 1,920 \\
\hline & June 4,1973 & 9.44 & 1,140 \\
\hline \multirow[t]{7}{*}{1974} & Apr. 29, 1974 & 9.66 & 1,230 \\
\hline & May 14,1974 & 12.00 & 2,270 \\
\hline & May 17,1974 & 13.93 & $5_{5,380}$ \\
\hline & May 29,1974 & 11.19 & 1,770 \\
\hline & June 9,1974 & 9.49 & 1,150 \\
\hline & June 23,1974 & 10.02 & 1,320 \\
\hline & Aug. 13, 1974 & 11.02 & 1,700 \\
\hline \multirow[t]{2}{*}{1975} & Mar. 19,1975 & 10.71 & 1,940 \\
\hline & Mar. 22, 1975 & 9.97 & 1,620 \\
\hline 1976 & Apr. 24,1976 & 9.06 & 1,030 \\
\hline \multirow[t]{2}{*}{1977} & Aug. 16, 1977 & 13.02 & 3,540 \\
\hline & Sept. 18,1977 & 10.82 & 1,620 \\
\hline
\end{tabular}


05454300 Clear Creek near Coralville, Iowa--Continued

Peak stages and discharges--Continued

\begin{tabular}{|c|c|c|c|}
\hline $\begin{array}{l}\text { Water } \\
\text { year }\end{array}$ & Date & $\begin{array}{l}\text { Gage height } \\
\text { (ft) }\end{array}$ & $\begin{array}{c}\text { Discharge } \\
\left(\mathrm{ft}^{3} / \mathrm{s}\right)\end{array}$ \\
\hline \multirow[t]{4}{*}{1978} & June 29,1978 & 12.94 & 3,360 \\
\hline & July $\quad 9,1978$ & 10.28 & 1,400 \\
\hline & July 19,1978 & 9.77 & 1,230 \\
\hline & July 22,1978 & 11.65 & 1,990 \\
\hline \multirow[t]{2}{*}{1979} & Mar. 19, 1979 & 12.41 & 2,590 \\
\hline & Aug. 20, 1979 & 10.71 & 1,570 \\
\hline 1980 & July 14,1980 & 7.23 & 632 \\
\hline \multirow[t]{3}{*}{1981} & June 24,1981 & 9.06 & 1,040 \\
\hline & June 29,1981 & 9.11 & 1,050 \\
\hline & Aug. $\quad 5,1981$ & 9.06 & 1,040 \\
\hline \multirow[t]{5}{*}{1982} & Feb. 22,1982 & ${ }^{1}(4)$ & 21,270 \\
\hline & June 15,1982 & 14.61 & 56,520 \\
\hline & July 13,1982 & (4) & 21,500 \\
\hline & July 19,1982 & 13.23 & $5_{3,600}$ \\
\hline & Aug. $\quad 8,1982$ & 12.73 & 4,050 \\
\hline \multirow[t]{5}{*}{1983} & Dec. 5,1982 & 9.17 & 1,060 \\
\hline & Apr. 2,1983 & 9.15 & 1,130 \\
\hline & June 28,1983 & 11.87 & 1,940 \\
\hline & June 29,1983 & 9.10 & 1,050 \\
\hline & July 2,1983 & 9.37 & 1,120 \\
\hline 1984 & Feb. 12,1984 & 8.80 & 1,010 \\
\hline \multirow[t]{3}{*}{1985} & Nov. 1,1984 & 9.90 & 1,270 \\
\hline & Feb. 22,1985 & 10.70 & 1,810 \\
\hline & Mar. $\quad 4,1985$ & 9.70 & 1,260 \\
\hline \multirow[t]{6}{*}{1986} & Apr. 30,1986 & 8.65 & 1,200 \\
\hline & May 17,1986 & 13.20 & 3,640 \\
\hline & May 26,1986 & 10.52 & 1,690 \\
\hline & June $\quad 5,1986$ & 10.73 & 1,650 \\
\hline & June 30,1986 & 13.32 & 4,100 \\
\hline & July 7,1986 & 8.62 & 1,050 \\
\hline
\end{tabular}




\section{Clear Creek near Coralville, Iowa--Continued}

Peak stages and discharges--Continued

\begin{tabular}{|c|c|c|c|}
\hline $\begin{array}{l}\text { Water } \\
\text { year }\end{array}$ & Date & $\begin{array}{c}\text { Gage height } \\
\text { (ft) }\end{array}$ & $\begin{array}{c}\begin{array}{c}\text { Discharge } \\
\left(\mathrm{ft}^{3} / \mathrm{s}\right)\end{array} \\
\end{array}$ \\
\hline 1987 & Aug. 26, 1987 & 7.73 & 809 \\
\hline 1988 & Jan. 19,1988 & ${ }^{1} 10.25$ & 1,660 \\
\hline 1989 & Sept. $\quad 9,1989$ & 7.99 & 1,040 \\
\hline 1990 & $\begin{array}{lr}\text { June } & 9,1990 \\
\text { June } & 17,1990 \\
\text { June } & 20,1990 \\
\text { July } & 29,1990 \\
\text { Aug. } & 20,1990 \\
\text { Aug. } & 25,1990\end{array}$ & $\begin{array}{r}8.52 \\
16.36 \\
9.71 \\
8.61 \\
13.09 \\
11.64\end{array}$ & $\begin{array}{r}1,020 \\
510,200 \\
1,270 \\
1,040 \\
5_{3,450} \\
2,060\end{array}$ \\
\hline 1991 & Mar. 2, 1991 & 9.30 & 1,180 \\
\hline 1992 & $\begin{array}{l}\text { July } 26,1992 \\
\text { July } 31,1992\end{array}$ & $\begin{array}{l}8.90 \\
9.47\end{array}$ & $\begin{array}{l}1,100 \\
1,220\end{array}$ \\
\hline 1993 & $\begin{array}{lr}\text { Nov. } & 21,1992 \\
\text { Nov. } & 22,1992 \\
\text { Mar. } & 3,1993 \\
\text { Mar. } & 23,1992 \\
\text { Apr. } & 20,1993 \\
\text { May } & 4,1993 \\
\text { May } & 7,1993 \\
\text { June } & 19,1993 \\
\text { June } & 25,1993 \\
\text { June } & 27,1993 \\
\text { June } & 30,1993 \\
\text { July } & 6,1993 \\
\text { July } & 9,1993 \\
\text { July } & 11,1993 \\
\text { July } & 24,1993 \\
\text { July } & 25,1993 \\
\text { July } & 31,1993 \\
\text { Aug. } & 10,1993 \\
\text { Aug. } & 12,1993 \\
\text { Aug. } & 14,1993\end{array}$ & $\begin{array}{r}11.55 \\
8.63 \\
11.32 \\
11.63 \\
11.05 \\
10.63 \\
8.51 \\
11.37 \\
9.03 \\
11.15 \\
10.82 \\
14.74 \\
10.43 \\
9.71 \\
12.83 \\
11.34 \\
13.45 \\
13.59 \\
9.05 \\
10.58\end{array}$ & $\begin{array}{l}2,010 \\
1,040 \\
2,210 \\
2,050 \\
1,780 \\
1,610 \\
1,020 \\
1,920 \\
1,130 \\
1,820 \\
1,690 \\
6,760 \\
1,540 \\
1,320 \\
2,960 \\
1,910 \\
4,520 \\
4,350 \\
1,130 \\
1,590\end{array}$ \\
\hline
\end{tabular}


$\mathbf{0 5 4 5 4 3 0 0}$ Clear Creek near Coralville, Iowa--Continued

Peak stages and discharges--Continued

\begin{tabular}{lccc}
\hline $\begin{array}{l}\text { Water } \\
\text { year }\end{array}$ & Date & $\begin{array}{c}\text { Gage height } \\
(\mathrm{ft})\end{array}$ & $\begin{array}{c}\text { Discharge } \\
\left(\mathrm{ft}^{3} / \mathrm{s}\right)\end{array}$ \\
\hline \multirow{2}{*}{1993} & Aug. 16, 1993 & 13.20 & 3,500 \\
& Aug. 29, 1993 & 11.50 & 1,980 \\
& Sept. 26, 1993 & 12.77 & 2,900 \\
\hline
\end{tabular}

${ }_{2}^{1}$ Affected by ice.

2 Approximate.

${ }^{3}$ Discharge not determined.

${ }_{5}^{4}$ Gage height not determined.

${ }^{5}$ Discharge revised from previously published value. 


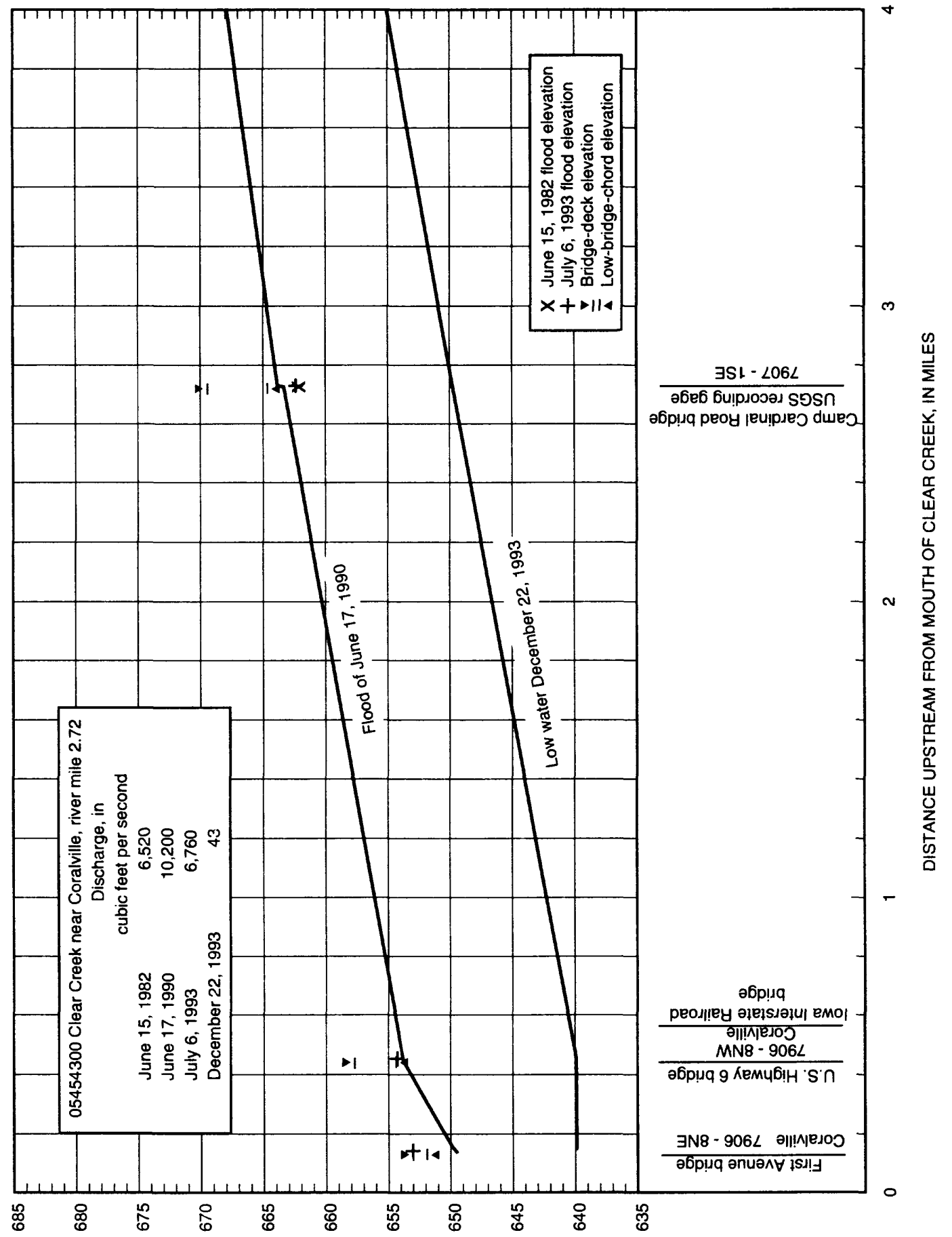

$1 \exists \exists \exists$ NI ‘ $า \exists \wedge \exists า \forall \exists S ~ \exists \wedge O 8 \forall N O I \perp \forall \wedge \exists า \exists$ 


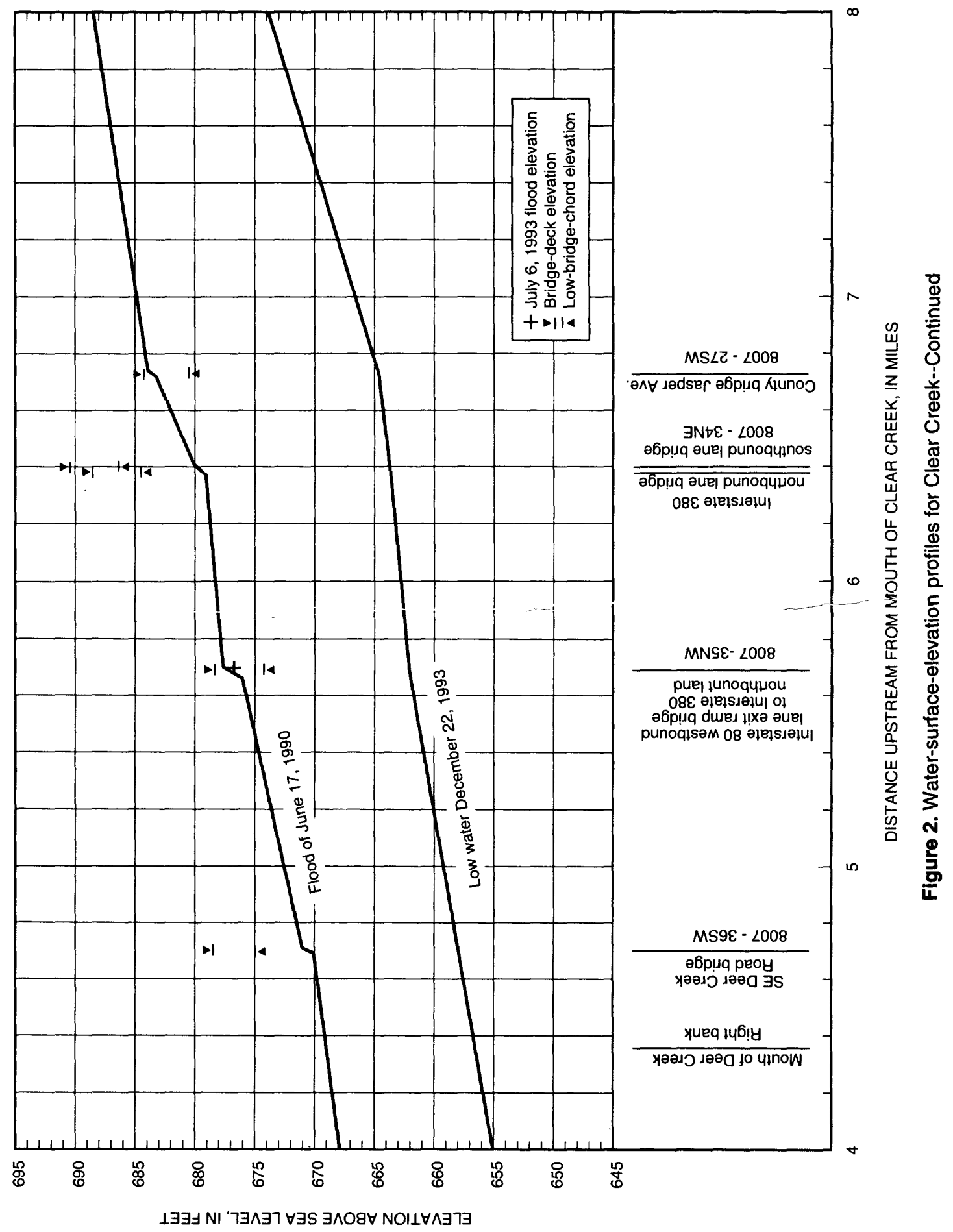




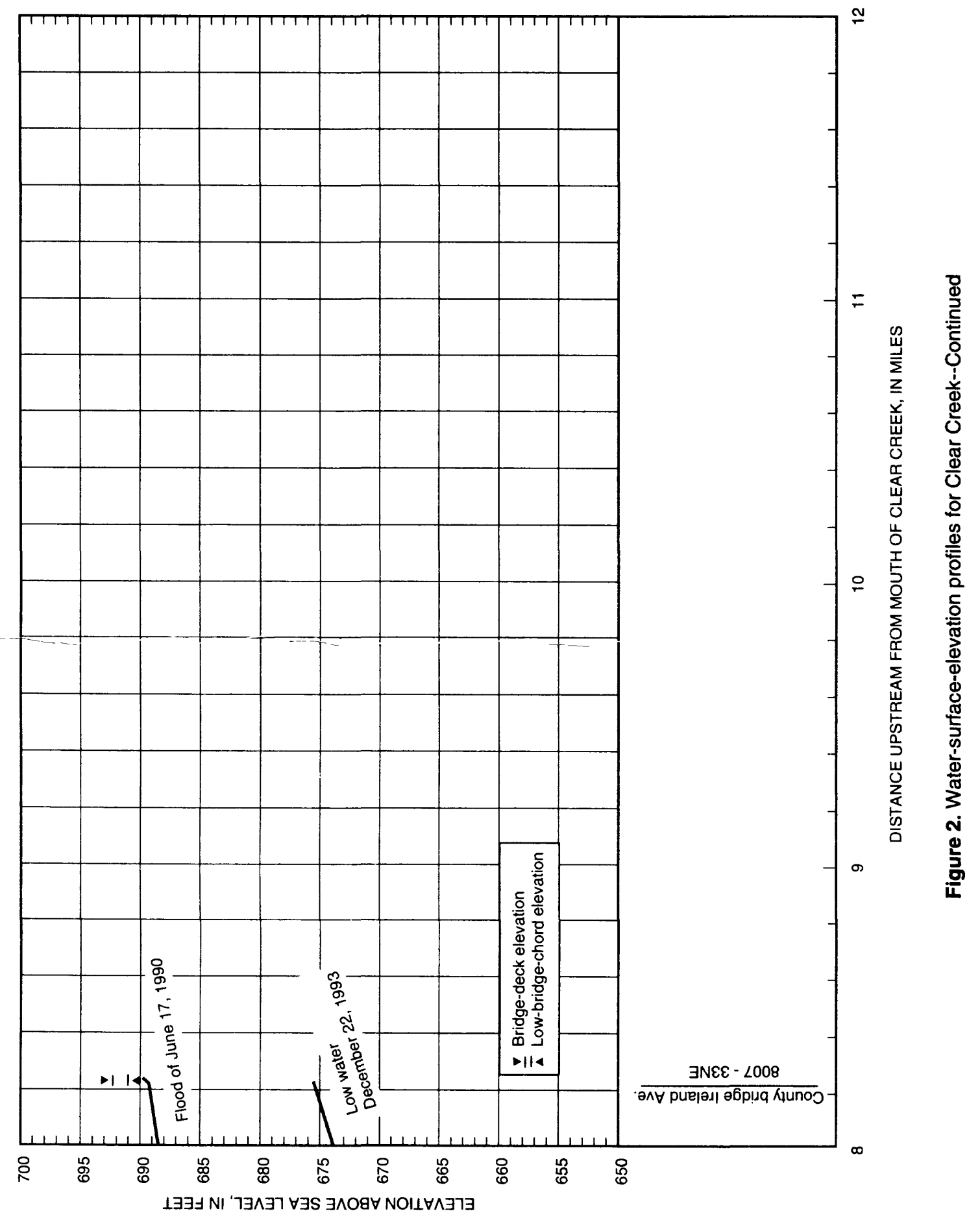


Appendix C. DESCRIPTIONS AND ELEVATIONS OF TEMPORARY BENCH MARKS AND REFERENCE POINTS IN THE CLEAR CREEK BASIN, EASTCENTRAL IOWA

The temporary bench marks (BM) and reference points (RP) listed in this tabulation were established during 1990-93 by the U.S. Geological Survey (USGS) except those for which credit is given in the descriptions. The work was done as a part of a stream-profile study jointly funded by the Iowa Highway Research Board, the Highway Division of the Iowa Department of Transportation, and the USGS.

BMs and RPs are identified by an index number composed of the township, range, section number, and the quarter section in which they are located. The township and range numbers are combined into a four-digit number, such as 7906 for Township 79 North and Range 6 West. This is followed by a dash and the section number in which the BM or RP is located. Within the section, the quarter section in which the BM or RP is located is designated by NE, SE, SW, or NW. A number in parentheses following this letter designation indicates the number of the $\mathrm{BM}$ or $\mathrm{RP}$ in that particular quarter section. The index number serves to describe the landline location of the BM or RP without further reference in the body of the description.

RPs are distinguished from BMs in this tabulation by the notation "REFERENCE POINT" following the index number. RPs were established to permit water-surface elevations to be determined by the use of a tape and weight.

Differential leveling was performed along Clear Creek from the Ireland Avenue bridge south of Tiffin to the First Avenue bridge in Coralville (figs. 1 and 2). BMs and RPs were established at the majority of bridges and at intermediate points to preserve the level lines.

Level lines to establish the third-order accuracy of the BMs and RPs shown herein were surveyed from first- or second-order bench marks established and adjusted by the National Geodetic Survey (NGS) or the National Mapping Division (NMD) of the USGS. Errors of closure in the USGS level work were adjusted along the level line to the elevations published by the NGS and the NMD. All elevations are referenced to sea level.

Standard BMs, such as chiseled squares and crosses, were used on concrete or steel. On trees or poles, a 20-penny pole spike driven horizontally through a short piece of 1/8-in. galvanized pipe or a railroad spike was used. Existing BMs were used wherever available, and the agency responsible for the bench mark, when known, is indicated in the description. Standard RPs, such as chiseled arrows, were used on concrete or steel. The terms "right" and "left" in the descriptions are determined as viewed while facing in the downstream direction of the flow of the stream.

The user of this information is cautioned that BMs and RPs may be disturbed or destroyed and can move over time. Many of the BMs and RPs that are listed herein are located on bridges that may have been repaired, replaced, or destroyed since the original level lines were surveyed. It is the responsibility of the user to determine the condition and the suitability of the BM or RP.

Additional information can be obtained by writing to the following address: U.S. Geological Survey, Water Resources Division, RM. 269, Federal Building, 400 South Clinton Street, Iowa City, IA 52244. 


\section{DESCRIPTIONS AND ELEVATIONS OF TEMPORARY BENCH MARKS AND REFERENCE POINTS IN THE CLEAR CREEK BASIN, EAST-CENTRAL, IOWA}

7906-05 SE (1)--At Coralville, along First Avenue about $0.4 \mathrm{mi}$ north of U.S. Highway 6 and about $20 \mathrm{ft}$ south of Iowa River Power Company driveway, $1 \mathrm{ft}$ south of first shrub south of driveway; an Iowa Geodetic Survey standard disk stamped "52-10" and set in the top of a concrete post flush with the ground.

Elevation $656.547 \mathrm{ft}$.

7906-08 NE (1)--At Coralville, on First Avenue bridge over Clear Creek, on upstream curb, on top of first 3/4-in. bolt from left bridge abutment; chiseled cross.

Elevation $654.36 \mathrm{ft}$.

7906-08 NE (2)--(REFERENCE POINT) At Coralville, on First Avenue bridge over Clear Creek, on upstream curb, $48 \mathrm{ft}$ from right bridge abutment; chiseled arrow.

Elevation $654.47 \mathrm{ft}$.

7906-08 NW (1)--At Coralville, on U.S. Highway 6 bridge over Clear Creek, on upstream sidewalk, $1.3 \mathrm{ft}$ north of left wingwall; Iowa Highway Commission bench mark.

Elevation $658.39 \mathrm{ft}$.

7906-08 NW (2)--(REFERENCE POINT) At Coralville, on U.S. Highway 6 bridge over Clear Creek, on upstream guardrail at 14th upright from left bridge abutment; three chiseled marks.

Elevation $661.01 \mathrm{ft}$.

7906-08 NW (3)--At Coralville, about $650 \mathrm{ft}$ south of U.S. Highway 6, on Iowa Railroad bridge over Clear Creek, on upstream bridge deck, on top of second 3/4-in. bolt from left side of bridge; chiseled cross.

Elevation $667.39 \mathrm{ft}$.

7907-01 SE (1)--About $1.1 \mathrm{mi}$ west of post office in Coralville, on Camp Cardinal Road bridge over Clear Creek, on left upstream curb on wingwall of bridge, U.S. Geological Survey bronze bench mark.

Elevation $668.33 \mathrm{ft}$.

8007-26 SW (1)--About 1.4 mi east of Tiffin and 0.4 mi east of Interstate 380, on north side of U.S. Highway 6, on culvert about $60 \mathrm{ft}$ west of first house east of Farm Service Feeds; Iowa Department of Transportation bench mark.

Elevation $691.71 \mathrm{ft}$.

8007-27 SE (1)--About 0.9 mi east of Tiffin and about $250 \mathrm{ft}$ west of Interstate 380 , on north side of U.S. Highway 6, on culvert about $40 \mathrm{ft}$ east of first house west of Interstate 380; Iowa Department of Transportation bench mark.

Elevation $683.00 \mathrm{ft}$.

8007-27 SW (1)--About 0.8 mi east of Tiffin, at intersection of U.S. Highway 6 and Jasper Avenue, in center of southwest concrete headwall of a 2- $\mathrm{x}$ 4-ft box culvert; U.S. Geological Survey standard tablet stamped "26 FDR 1964 682" painted "BM 682.2."

Elevation $682.155 \mathrm{ft}$.

8007-27 SW (2)--About 0.8 mi east of Tiffin, on Jasper Avenue bridge over Clear Creek, on top of right downstream wingwall; chiseled square. 
8007-27 SW (3)--(REFERENCE POINT) About $0.8 \mathrm{mi}$ east of Tiffin, on Jasper Avenue bridge over Clear Creek, on downstream guardrail, about one-third of bridge length from right abutment; chiseled arrow.

Elevation $687.28 \mathrm{ft}$.

8007-33 NW (1)--About $0.25 \mathrm{mi}$ south of Tiffin, on Ireland Avenue bridge over Clear Creek, on curb at left downstream abutment; Iowa Highway Commission bench mark.

Elevation $693.42 \mathrm{ft}$.

8007-33 NW (2)--About 0.25 mi south of Tiffin, on Ireland Avenue bridge over Clear Creek, on wingwall at left downstream abutment; chiseled square.

Elevation $695.16 \mathrm{ft}$.

8007-33 NW (3)--(REFERENCE POINT) About $0.25 \mathrm{mi}$ south of Tiffin, on Ireland Avenue bridge over Clear Creek, on upstream guardrail at eighth upright from right bridge abutment; chiseled arrow.

Elevation $694.91 \mathrm{ft}$.

8007-34 NE (1)--About $1 \mathrm{mi}$ east of Tiffin, on northbound lane of Interstate 380 bridge over Clear Creek (downstream bridge), on top of downstream concrete barrier wall at left end of bridge; Iowa Department of Transportation bench mark. Elevation obtained from Iowa Department of Transportation.

Elevation $694.73 \mathrm{ft}$.

8007-34 NE (2)--(REFERENCE POINT) About $1 \mathrm{mi}$ east of Tiffin, on northbound lane of Interstate 380 bridge over Clear Creek (downstream bridge), on top of downstream concrete barrier wall approximately $92 \mathrm{ft}$ from Iowa Department of Transportation bench mark 8007-34 NE (1); chiseled arrow.

Elevation $692.62 \mathrm{ft}$.

8007-35 NW (1)--About 1.7 mi southeast of Tiffin, on exit ramp bridge over Clear Creek of westbound lane of Interstate 80 to northbound lane of Interstate 380 (most upstream bridge), on curb near left upstream bridge abutment; Iowa Highway Commission bench mark.

Elevation $679.17 \mathrm{ft}$.

8007-35 NW (2)--(REFERENCE POINT) About 1.7 mi southeast of Tiffin, on exit ramp bridge over Clear Creek of westbound lane of Interstate 80 to northbound lane of Interstate 380 (most upstream bridge), on upstream guardrail at 12 th upright from left bridge abutment; chiseled arrow.

Elevation $681.54 \mathrm{ft}$.

8007-36 SW (1)--About $2.3 \mathrm{mi}$ northwest of post office in Coralville and about $300 \mathrm{ft}$ south of U.S.

Highway 6, on SE Deer Creek Road bridge over Clear Creek, on top of right upstream wingwall; Iowa Department of Transportation bench mark.

Elevation $681.03 \mathrm{ft}$.

8007-36 SW (2)--(REFERENCE POINT) About 2.3 mi northwest of post office in Coralville and about $300 \mathrm{ft}$ south of U.S. Highway 6, on SE Deer Creek Road bridge over Clear Creek, downstream side of bridge, on downstream guardrail at 15 th upright from right bridge abutment; chiseled arrow.

Elevation $682.27 \mathrm{ft}$. 